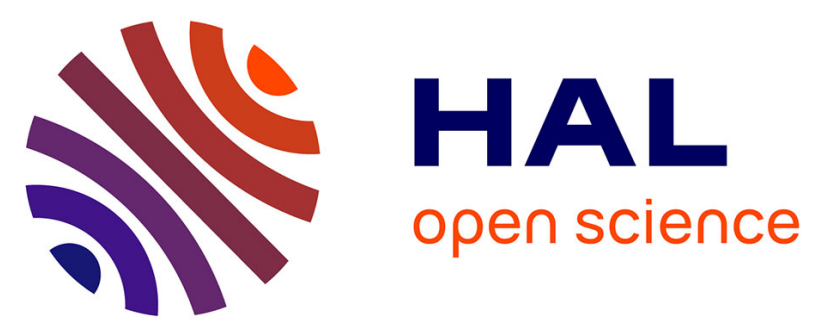

\title{
Infiltration Column for Studying the Lateral Swell Behavior of Expansive Clay
}

Simona Saba, Yu-Jun Cui, Jean-Dominique Barnichon, Anh Minh A.M. Tang

\section{To cite this version:}

Simona Saba, Yu-Jun Cui, Jean-Dominique Barnichon, Anh Minh A.M. Tang. Infiltration Column for Studying the Lateral Swell Behavior of Expansive Clay. Geotechnical Testing Journal, 2016, 39 (3), pp.407-414. 10.1520/GTJ20150151 . hal-01515792

\section{HAL Id: hal-01515792 \\ https://hal-enpc.archives-ouvertes.fr/hal-01515792}

Submitted on 3 May 2017

HAL is a multi-disciplinary open access archive for the deposit and dissemination of scientific research documents, whether they are published or not. The documents may come from teaching and research institutions in France or abroad, or from public or private research centers.
L'archive ouverte pluridisciplinaire HAL, est destinée au dépôt et à la diffusion de documents scientifiques de niveau recherche, publiés ou non, émanant des établissements d'enseignement et de recherche français ou étrangers, des laboratoires publics ou privés. 


\section{An infiltration column for studying the lateral swell behavior of expansive}

2 clay

3

$4 \quad{ }^{1}$ Ecole des Ponts ParisTech, Laboratoire Navier\CERMES, 6 - 8 avenue Blaise Pascal 77455

5 Marne-La-Vallée, France

$6 \quad{ }^{2}$ Institut de Radioprotection et de Sûreté Nucléaire (IRSN), BP 1792262 Fontenay aux

7 Roses, France

8

9

10

11

12

13 Corresponding author:

14 Dr. Anh Minh TANG

15 Ecole des Ponts ParisTech

$16 \quad 6-8$ avenue Blaise Pascal

1777455 MARNE-LA-VALLEE

18 France

19 Email : anhminh.tang@enpc.fr

$20 \quad$ Tel: $+33(0) 164153563$

21 Fax: +33(0) 164153562

22 
1 Abstract: Infiltration column is usually used to investigate the hydro-mechanical processes in

2 unsaturated expansive clay. In this test, the moisture transfer is often monitored along the

3 column during water infiltration using suction or water content probes. Nevertheless, the

4 lateral swelling pressure developed is rarely considered. This paper describes an infiltration

5 column for studying the lateral swell behavior of expansive clay. The column consists of a

6 rigid cell ensuring the constant-volume condition and a hydraulic system enabling the water

7 intake of the hosted sample. It is equipped with three types of sensors: pressure sensors, force

8 transducer and displacement transducer to respectively monitor the radial and axial swelling

9 pressure of the sample at different positions and to check whether any axial displacement is

10 taking place. A detailed description of the different parts of the cell is first presented.

11 Secondly, analysis on the results of a test on a compacted bentonite/sand mixture allows the

12 pertinence of such device to be evaluated.

13

14 Keywords: infiltration column; expansive clay; swelling pressure; local measurement, 15 constant volume conditions.

16

17 


\section{Introduction}

2 Hydro-mechanical processes in unsaturated expansive clay need to be considered when

3 studying the damage to buildings, structures and roads caused by ground movement related to

4 moisture transfer (Basma et al. 1996; Tang et al. 2009a). In addition, compacted expansive

5 clays are increasingly used for engineered barriers for environmental protection (Gens 2010).

6 Infiltration column is usually used in laboratory to investigate the moisture transfer in

7 compacted expansive clay where soil suction (or moisture content) is monitored along the

8 column (Cui et al. 2008; Tang et al. 2009b; Wang et al. 2013a). However, it is well known

9 that wetting unsaturated expansive clay under constant-volume condition induces swelling

10 pressure. In the laboratory, where the compacted clay sample is confined in a rigid cell during

11 saturation, the swelling pressure is usually measured in the axial direction of the cell (Pusch

12 1982; Komine and Ogata 1994; Agus and Schanz 2005; Wang et al. 2012). Few works exist

13 monitoring the lateral swelling pressure of compacted expansive clay (Cho et al. 2000; Lee et

14 al. 2012).

The above-mentioned laboratory works on swelling pressure of expansive clay consist however only elementary tests. Large-scale in situ experiments were also performed to monitor the moisture transfer and the coupled hydro-mechanical behavior of compacted expansive clay (Chijimatsu et al. 2001; Alonso et al. 2005; Barnichon et al. 2012; Wang et al. $2013 b$ ). In these experiments, the swelling pressure developed during wetting was measured at various locations using total pressure transducers embedded in the soil. Nevertheless,

22 performing in situ experiments remains complexes. For this reason, various mock-up tests have been done to study the hydro-mechanical behavior of expansive soil (Martin and Barcala

24 2005; Pacovsky et al. 2007). These tests still require large size sample and the installation of total pressure transducers are similar to that of in situ experiments. 
2 When using small-scale mock-up test to study the hydro-mechanical behavior of compacted 3 expansive clay, column-type testing device is usually used (Schanz et al. 2013; Wang et al.

$42013 a$ ). In these works, the swelling pressure was measured in the axial direction of the

5 column. As a consequence, the development of lateral swelling pressure during infiltration 6 could not be observed.

8 In the present work, an infiltration column equipped with radial swelling pressure transducers, 9 installed at various locations along the column, is presented. The results of an experiment on a bentonite/sand mixture allow evaluating the pertinence of the device to investigate the hydro11 mechanical processes when wetting compacted expansive clay under constant-volume condition.

\section{Soil studied}

The soil studied is a mixture of bentonite/sand with a dry mass fraction of 70/30. The bentonite is MX80 from Wyoming, USA, having a liquid limit of 575\%, a plastic limit of

$1753 \%$ and a particle density of $2.77 \mathrm{Mg} / \mathrm{m}^{3}$. This bentonite is known to have a high water 18 intake capacity with a specific surface as large as $710 \mathrm{~m}^{2} / \mathrm{g}$. The sand (pure quartz) used in the 19 mixture has a particle density of $2.65 \mathrm{Mg} / \mathrm{m}^{3}$. It was sieved at $2 \mathrm{~mm}$ prior to being mixed with 20 bentonite grains that were previously equilibrated with a water content $(w)$ of $13 \%$. The grain 21 size distribution curves of the bentonite and sand grains were determined by dry sieving and 22 are presented in Figure 1. The figure shows that the size of bentonite grains was similar to that 23 of sand grains. Once the bentonite was deflocculated in water, the particle size distribution 24 bentonite determined by the hydrometer method show that it contains mainly fine particles 
$1 \quad(80 \%$ smaller than $0.001 \mathrm{~mm})$.

3 The present study is part of the SEALEX project where in situ experiments were conducted to

4 study the performance of compacted bentonite seals (Barnichon et al. 2012). In the SEALEX

5 in situ experiments, the water used to saturate the compacted soil has similar chemical

6 composition as the pore water of claystone considered as the host rock in the French program

7 of geological radioactive waste disposal. This water was also used in this study and its 8 chemical composition is shown in Table 1.

\section{Experimental set-up}

11 The experimental set-up is presented in Figure 2 and consists of several parts: $i$ ) the 12 mechanical part that hosts the soil sample; $i i)$ the hydraulic part that enables the saturation of 13 the sample; iii) the monitoring part with all the sensors (total pressure, force transducer, 14 displacement indicator) and the data logger system.

15 For the mechanical part, a stainless steel cell was designed to mechanically ensure the 16 constant-volume condition of the experiment. It consists of a hollow cylinder of $11 \mathrm{~mm}$ 17 thickness fixed to a thick base. In the axial direction, a piston is placed on the top of the soil 18 specimen and is blocked by a screw that is fixed to a stiff structure (Figure 3). This stiff structure consists of two stainless steel disks respectively placed on the two sides of the cylinder, connected by three metallic rods. The cell was designed to withstand high pressure 21 up to $18 \mathrm{MPa}$. The force due to axial soil swelling is directly transmitted to the screw, and 22 then to the stiff structure (disks and rods).

24 For the hydraulic part, the base of the cell, on which the cylinder was mounted, is equipped 
1 with water inlet and outlet (Figure 2). The water inlet is connected to a burette and then to a

2 water tank. The graduated burette shows the volume of water entering the cell, and it is 3 regularly supplied with water from the water tank.

5 To monitor the lateral swelling pressure, six total pressure sensors (PS) were installed at

6 different positions as shown in Figure 4. They are labeled according to their distance to the

7 bottom of the sample; for instance PS20, PS40, PS60, PS80, PS100 and PS120 situated at 20,

$840,60,80,100$ and $120 \mathrm{~mm}$ respectively from bottom of the sample. Due to the small size of

9 the soil specimen ( $60 \mathrm{~mm}$ in diameter), miniature pressure sensors are used here. A force

10 transducer is placed under the cell base to measure the axial swelling pressure of the specimen

11 (Figure 3). A digital displacement transducer is installed to measure the displacement of the 12 piston. The displacement of the piston is measured mainly to verify the constant-volume 13 condition.

\section{Test procedure}

16 The bentonite/sand mixture was statically compacted in the column. The target dimensions of 17 the sample are $120 \mathrm{~mm}$ in height and $60 \mathrm{~mm}$ in diameter. The target dry density of the sample 18 is $1.67 \mathrm{Mg} / \mathrm{m}^{3}$ (similar to that studied by Wang et al. 2013a). In order to obtain a 19 homogeneous sample, it was compacted in 3 layers of $40 \mathrm{~mm}$ height each. The sample was

20 directly compacted in the cell after closing the holes of sensors in the cell's wall by screwing 21 solid plugs having the same shape of the pressure sensors. The inner wall of the cylinder was 22 coated with grease in order to minimize the friction between the soil and the cell. The details

23 of the three layers forming the sample after compaction are presented in Figure 5; where $\rho_{d}$ is 24 the dry density of the compacted layer and $\rho_{d b}$ is the bentonite dry density in the compacted 
1 layer. The bentonite dry density $\left(\rho_{d b}\right)$ was determined based on the density of the compacted

2 mixture $\left(\rho_{m}\right)$, the specific gravity of sand $\left(G_{s s}\right)$, the water content of the mixture $\left(w_{m}\right)$ and the

3 bentonite content in dry mass $(B)$ as follows (Wang et al., 2013c):

$4 \quad \rho_{d b}=\frac{(B / 100) \rho_{m} G_{s s}}{G_{s s}\left(1+w_{m} / 100\right)-\rho_{m}(1-B / 100)}$

5 The obtained sample height was $118.2 \mathrm{~mm}$ (the target was $120 \mathrm{~mm}$ ) and the mean density

6 obtained was $1.69 \mathrm{Mg} / \mathrm{m}^{3}$, close to the target density $\left(1.67 \mathrm{Mg} / \mathrm{m}^{3}\right)$. The hydraulic

7 conductivity at saturated state of this material is very low $\left(10^{-13} \mathrm{~m} / \mathrm{s}\right)$ and more details about

8 the hydraulic conductivity at unsaturated state can be found in Wang et al. (2013a).

10 After the compaction of the specimen, the cell was placed on the tray of the force transducer

11 and then the two stainless steel plates were fixed with three rods. The central screw was

12 adjusted to touch the piston and to apply an initial pressure of $100 \mathrm{kPa}$. This pressure was

13 expected to allow a good contact between the cell, the piston and the sample. The radial

14 sensors were then screwed to the cell wall and adjusted so that an initial pressure of $100 \mathrm{kPa}$ was also applied to ensure a good contact between the sensor and the sample.

Water infiltration was then performed from the bottom side of the specimen. The evolutions of axial and radial swelling pressures were recorded during hydration as well as the axial displacement of the piston. The injected water was monitored continuously by noting the water level in the burette every day.

\section{Results}

23 Figure 6 shows the piston axial displacement during the experiment. The results of the test 
1 performed by Wang et al. (2013b) are also presented in this figure. For the present study, the

2 displacement increased over time and reached $0.32 \mathrm{~mm}, 0.27 \%$ of the sample height.

4 The swelling pressure versus elapsed time is presented in Figure 7. Initial values are close to 0.1 MPa except for the sensor PS80 that started from a higher value (0.6 MPa). Actually, it

6 was difficult to adjust the position of the sensor to have an exact initial pressure value of 0.1

$7 \mathrm{MPa}$. On the whole, the swelling pressure increased over time except for the one 8 corresponding to the sensor PS120. Actually, this sensor was not in contact with the sample 9 having a height of $118.2 \mathrm{~mm}$. For the other sensors, the rate of increase was different depending on their positions. A higher rate was found for the sensors that were closer to the

11 wetting source, the highest rate being logically observed for sensor PS20 that was the closest to the bottom. The curve corresponding to this sensor exhibits a first quick increase, reaching 13 a peak value followed by a slight decrease and then a very slow increase to stabilize at around 3.5 MPa. The swelling pressure evolution measured by the sensor PS40 was similar to that of PS20. The curves relative to sensors PS60 and PS80 increased at similar initial rates in the beginning and reached a peak at around 5.0 $\mathrm{MPa}$. The values at the end of the test were 17 respectively 4.4 $\mathrm{MPa}$ and $4.3 \mathrm{MPa}$. At $100 \mathrm{~mm}$ height, a lower increase rate was observed; a 18 peak was reached at 4.2 MPa followed by a continuous decrease with a final value of 3.6 $19 \mathrm{MPa}$. The axial swelling pressure curve presented the lowest initial increase rate; it reached a peak at around $5 \mathrm{MPa}$ followed by a decrease.

The volume of injected water that was monitored manually is presented versus time in Figure 238 together with the results reported by Wang et al. (2013b) in a similar test with the same 24 sample dimensions and density. A quick increase is observed at the beginning followed by an increase at a lower rate. The theoretical total volume, $75 \mathrm{~mL}$, corresponds to the fully 
1 saturated state of the sample was calculated as the volume of the total air-void in the sample at

2 the initial state. This latter is the difference between the volume of the sample and that of the

3 of bentonite and sand grains. It can be calculated using the following equation:

$$
\begin{aligned}
& V_{\text {air void }}=V_{\text {sample }}-\left(V_{\text {wet bentonite }}+V_{\text {sand }}\right) \\
& \qquad=V_{\text {sample }}-\left(\left(\frac{m_{\text {dry bentonite }}}{G_{s b}}+\frac{m_{\text {water }}}{\rho_{w}}\right)+\frac{m_{\text {sand }}}{G_{s s}}\right)
\end{aligned}
$$

4 Where $G_{s b}$ and $G_{s s}$ are the specific gravities of bentonite and sand respectively.

\section{Discussion}

7 The aim of the work is to study the water infiltration and the lateral swelling behavior of compacted expansive clay under constant-volume condition. Nevertheless, the results show that a small axial swelling strain can be observed (Figure 6). The maximal axial displacement equals $0.32 \mathrm{~mm}(0.27 \%$ of the sample height $)$ can be considered negligible. This value is

11 slightly higher than that observed by Wang et al. (2013b) where a similar system was used.

12 Actually, axial swelling pressure reached in the present work (5 MPa) is higher than that observed by Wang et al. (2013b), 1.8 MPa.

The final values of swelling pressure measured are in the range of $3.5 \mathrm{MPa}$ to $4.5 \mathrm{MPa}$ (Figure 7), for a mean value dry density of $1.69 \mathrm{Mg} / \mathrm{m}^{3}$. This range is also compatible with

17 those obtained by other authors on the same material (Karnland et al. 2008; Wang et al.

$182013 c$ ). As far as the kinetics of swelling pressure, and more specifically the increase rate, is 19 concerned, it was observed that the initial increase was quicker when the measure was closer 20 to the wetting face. The axial swelling pressure measured by the force transducer then 21 corresponds to that at the farthest position from the wetting source; thus, its initial increase 
1 rate was found, as expected, to be the lowest. In fact, during the infiltration test, the material

2 progressively absorbed water and it took more time to reach the upper layers. This is similar

3 to most infiltration tests where the recorded data is the relative humidity (Wang et al. 2013a).

4 The kinetics of relative humidity was found to be similar to the swelling pressure kinetics 5 observed in the present work.

7 Saba et al. (2014a) investigated the anisotropy on the swelling pressure of the same material 8 and found that the axial swelling pressure is slightly higher than the lateral one. In the present 9 work, the final value of axial swelling pressure is also higher than the final values of radial ones. Even if, at the beginning of the experiment, the radial stress exceeds the axial stress. But 11 this can be explained by the fact that the axial swelling pressure corresponds to the farthest 12 position from the wetting source.

14 The volume of water injected after 180 days, $50 \mathrm{~mL}$, was still much lower than the value estimated to saturate the specimen, $75 \mathrm{~mL}$, see Figure 8. In the work of Wang et al. (2013b), $70 \mathrm{~mL}$ of water was injected after 180 days. Actually, in the work of Wang et al. (2013b), an

17 annular void exists at the beginning of the test which allow a quick injection of water at the 18 start of the test (more than $50 \mathrm{~mL}$ injected after the first hour). In addition, the volume of 19 water infiltrated at 20 days from Wang et al. (2013b) is $60 \mathrm{ml}$ while in this work it is $20 \mathrm{ml}$. 20 With less water the mixture would be expected to have lower axial swelling pressure (then 21 lower axial displacement of the piston). However it is contrary to the presented test results 22 (Figure 6). Actually, the presence of the annular void that exists at the beginning of the test 23 performed by Wang et al. (2013b) induced a significant decrease of swelling pressure after 12 24 days of infiltration. That annular void did not exist in the present work. 
2 In the present work, the results obtained from only one experimental are presented. Due to the 3 long duration of the experiment (180 days), it was not easy to repeat it to evaluate the

4 duplicability of method. However, the reliability of the data can be appreciated by its 5 agreement with existing data as discussed above. In addition, the results shown in the present 6 paper have been equally analyzed with other infiltration tests (Saba et al. 2014b), which 7 confirm the pertinence of the experimental device used.

\section{Conclusion}

10 The development of an infiltration column for studying the lateral swell behavior of expansive

11 clay is reported. The results of an experiment performed on compacted bentonite/sand mixture 12 are shown. When the bottom of the column was flooded with water, lateral swelling pressure developed progressively along the column. The rate of the increase of swelling pressure was higher for the sensor situated closer to the wetting front. The kinetic of swelling pressure change versus elapsed time at various location was similar to that obtained in an infiltration test with measurement of relative humidity. The final values of lateral swelling pressure, after

17180 days of flooding, were close to that reported in literature. In addition, these values were slightly lower than the axial one, which was also in agreement with the anisotropy of the material that was uni-axially compacted. The results obtained confirm the pertinence of the device to study the mechanical behavior of expansive clay subjected to water infiltration 21 under constant volume condition.

\section{References}

24 Agus, S. and Schanz, T., 2005, "Swelling pressures and wetting-drying curves of a highly 
compacted bentonite-sand mixture," Unsaturated Soils: Experimental Studies, pp. 241-256.

Alonso, E. E., Alcoverro, J. and Coste, F., 2005 "The FEBEX benchmark test: case definition and comparison of modelling approaches," International Journal of Rock Mechanics \& Mining Science, Vol. 42, Nos. 5-6, pp. $611-638$.

Barnichon, J. D., Dick, P. and Bauer, C., 2012, "The SEALEX in situ experiments: performance test of repository seals," Harmonising Rock Engineering and the Environment - Qian \& Zhou (eds) Taylor \& Francis Group, London, pp. 1391-1394.

Basma, A., Al-Homoud, A.S., Husein Malkawi, A.I. and Al-Bashabsheh, M., 1996, "Swelling-shrinkage behavior of natural expansive clays," Applied Clay Science, Vol. 11, Nos. 2-4, pp. 211-227.

Chijimatsu, M., Fujita, T., Sugita, Y., Amemiya, K. and Kobayashi, A., 2001, "Field experiment, results and THM behavior in the Kamaishi mine experiment," International Journal of Rock Mechanics and Mining Sciences, Vol. 38, No. 1, 67-78.

Cho, W. J., Lee, J. O. and Kang, C. H., 2000, "Influence of temperature elevation on the sealing performance of a potential buffer material for a high-level radioactive waste repository," Ann. Nucl. Energy, Vol. 27, pp. 271-1284.

Cui, Y.J., Tang, A.M., Loiseau, C. and Delage, P., 2008, "Determining the unsaturated hydraulic conductivity of a compacted sand-bentonite mixture under constant-volume and free-swell conditions," Physics and Chemistry of the Earth, Parts A/B/C, Vol. 33(Supplement 1), pp. S462 - S471.

Gens, A., 2010, "Soil-environment interactions in geotechnical engineering," Géotechnique, Vol. 60, No. 1, pp. 3-74.

Karnland, O., Nilsson, U., Weber, H. and Wersin, P., 2008, "Sealing ability of Wyoming bentonite pellets foreseen as buffer material - Laboratory results," Physics and Chemistry of the Earth, Vol. 33, pp. S472-S475.

Komine, H. and Ogata, N., 1994, "Experimental study on swelling characteristics of compacted bentonite," Canadian Geotechnical Journal, Vol. 31, No. 4, pp. 478-490.

Lee, J.O., Lim, J.G., Kang, I.M. and Kwon, S., 2012, "Swelling pressures of compacted Cabentonite," Engineering Geology, Vols 129-130, pp. 20 - 26.

Martín, P. L. and Barcala, J. M., 2005, "Large scale buffer material test: Mock-up experiment at CIEMAT," Engineering Geology, Vol. 81, No. 3, pp. 298-316.

Pacovský, J., Svoboda, J. and Zapletal, L., 2007, "Saturation development in the bentonite barrier of the Mock-Up-CZ geotechnical experiment," Physics and Chemistry of the Earth, Vol. 32, Nos. 8-14, pp. 767-779.

Pusch, R., 1982, "Mineral-water interactions and their influence on the physical behavior of highly compacted Na bentonite," Canadian Geotechnical Journal, Vol. 19, No. 3, pp. 381387.

Saba, S., Barnichon, J.D., Cui, Y.J. and Tang, A.M., 2014a, "Microstructure and anisotropic swelling behaviour of compacted bentonite/sand mixture," Journal of Rock Mechanics and Geotechnical Engineering, Vol. 6, No. 2, pp. 126-132.

Saba, S., Cui, Y.J., Tang, A.M. and Barnichon, J.D., 2014b, "Investigation of the swelling behaviour of compacted bentonite/sand mixture by mock-up tests," Canadian Geotechnical Journal, Vol. 51, No. 12, pp. 1399 - 1412. 
Schanz, T., Nguyen-Tuan, L. and Datcheva, M., 2013, "A column experiment to study the thermo-hydro-mechanical behaviour of expansive soils," Rock Mechanics and Rock Engineering, Vol. 46, No. 6, pp. 1287-1301.

Tang, A. M., Cui, Y. J., Trinh, V. N., Szerman, Y. and Marchadier, G., 2009a, "Analysis of the railway heave induced by soil swelling at a site in southern France," Engineering Geology, Vol. 106, Nos 1-2, pp. 68-77.

Tang, A.M., Ta, A.N. and Cui, Y.J., 2009b, "Development of a Large-Scale Infiltration Tank for Determination of the Hydraulic Properties of Expansive Clays," Geotechnical Testing Journal, Vol. 32, No. 5, pp. 385 - 396.

Wang, Q., Tang, A. M., Cui, Y.J., Delage, P. and Gatmiri, B., 2012, "Experimental study on the swelling behaviour of bentonite/claystone mixture," Engineering Geology, Vol. 124, pp. $59-66$.

13 Wang, Q., Cui, Y.J., Tang, A. M., Barnichon, J. D., Saba, S. and Ye, W.M., $2013 a$. "Hydraulic conductivity and microstructure changes of compacted bentonite/sand mixture during hydration," Engineering Geology, Vol. 164, pp. 67 - 76.

16 Wang, Q., Tang, A. M., Cui, Y.J., Barnichon, J.D. and Ye, W.M., 2013b, "A comparative study on the hydro-mechanical behaviour of compacted bentonite/sand plug based on laboratory and field infiltration tests," Engineering Geology, Vol. 162, pp. 79-87. effects of technological voids on the hydro-mechanical behaviour of compacted bentonitesand mixture. Soils and Foundations, 53(2), 232-245. 
Table 1. Chemical composition of synthetic water (Wang et al., 2012).

\begin{tabular}{|l|c|c|c|c|c|c|c|}
\hline Component & $\mathrm{NaHCO}_{3}$ & $\mathrm{Na}_{2} \mathrm{SO}_{4}$ & $\mathrm{NaCl}$ & $\mathrm{KCl}$ & $\mathrm{CaCl}_{2} \cdot 2 \mathrm{H}_{2} \mathrm{O}$ & $\mathrm{MgCl}_{2} \cdot 6 \mathrm{H}_{2} \mathrm{O}$ & $\mathrm{SrCl}_{2} \cdot 6 \mathrm{H}_{2} \mathrm{O}$ \\
\hline $\begin{array}{l}\text { Mass/Volum } \\
\text { e of solution } \\
\text { (g/L) }\end{array}$ & 0.28 & 2.216 & 0.615 & 0.075 & 1.082 & 1.356 & 0.053 \\
\hline
\end{tabular}




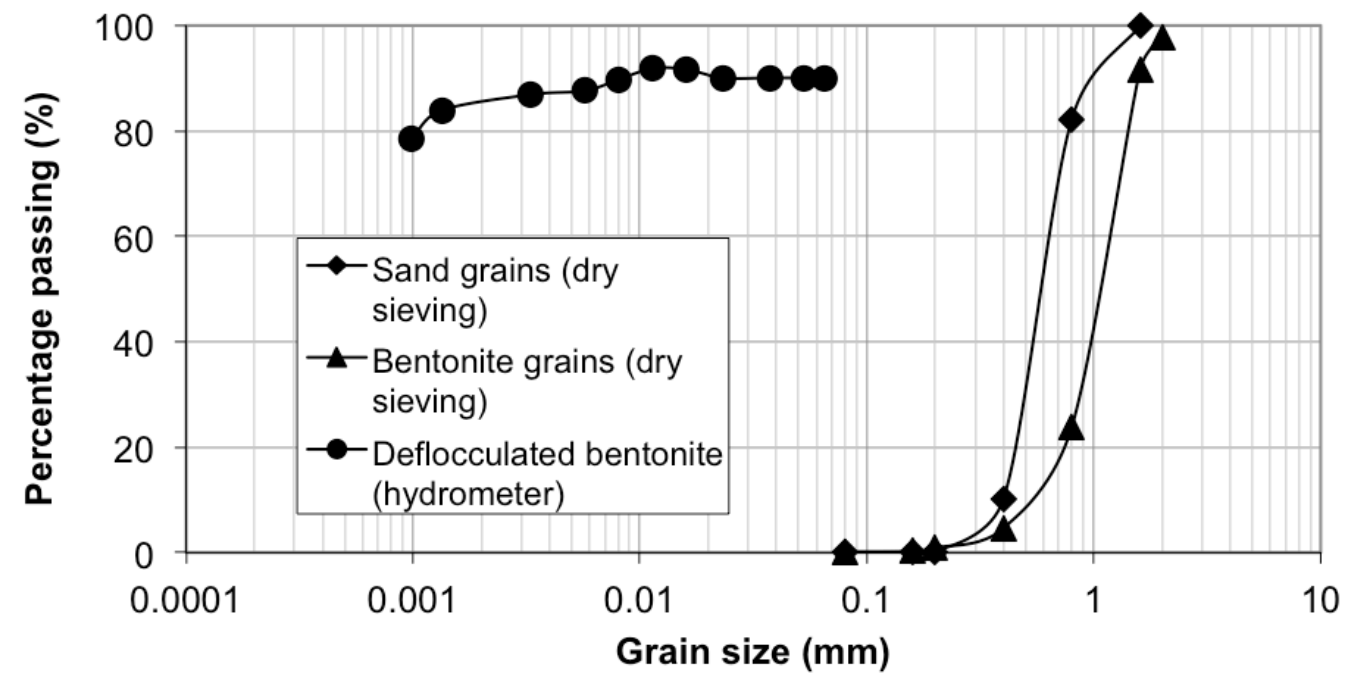

Figure 1. Grain size distribution curves. 


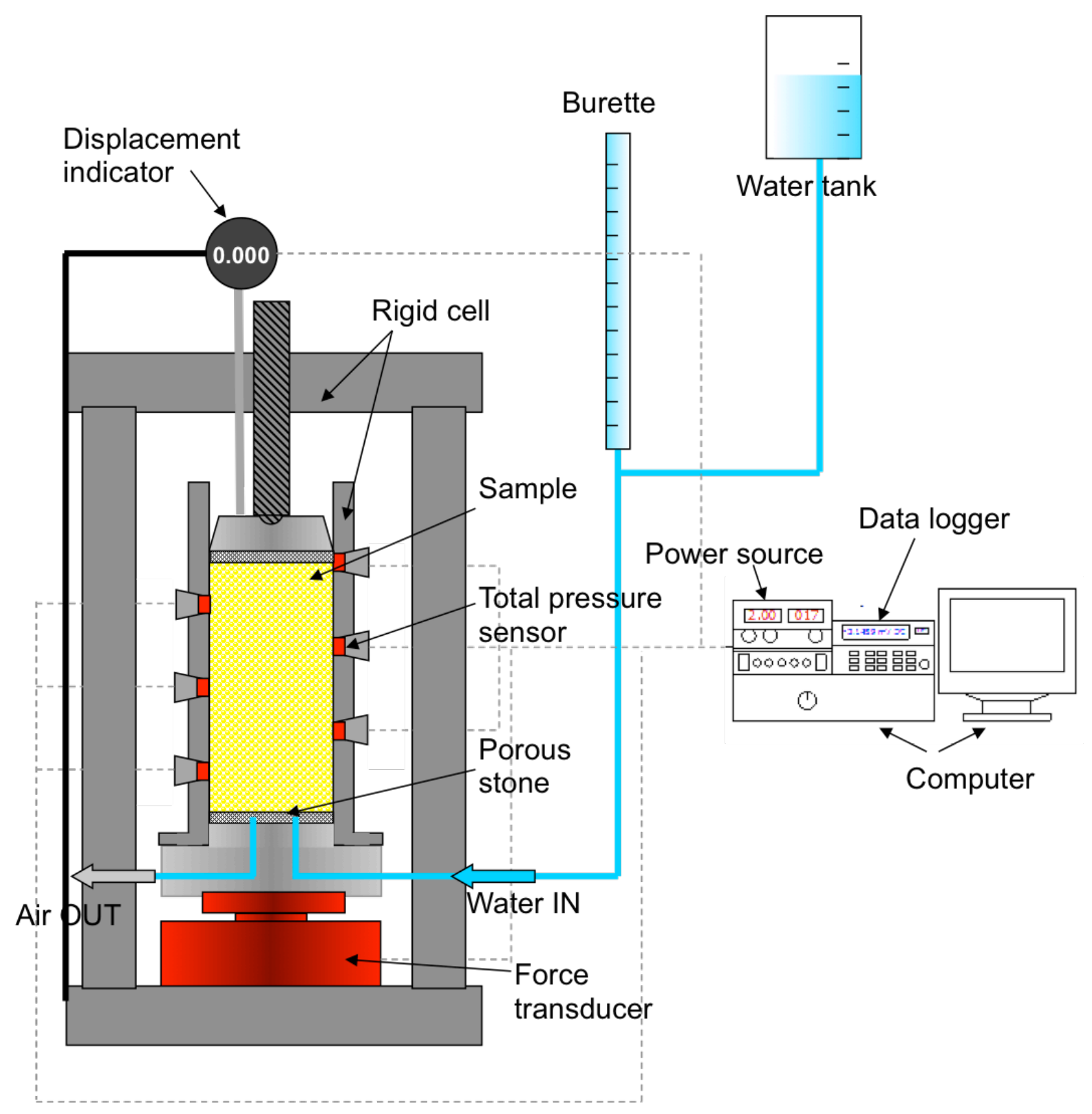

Figure 2. Outline of the experimental set-up. 


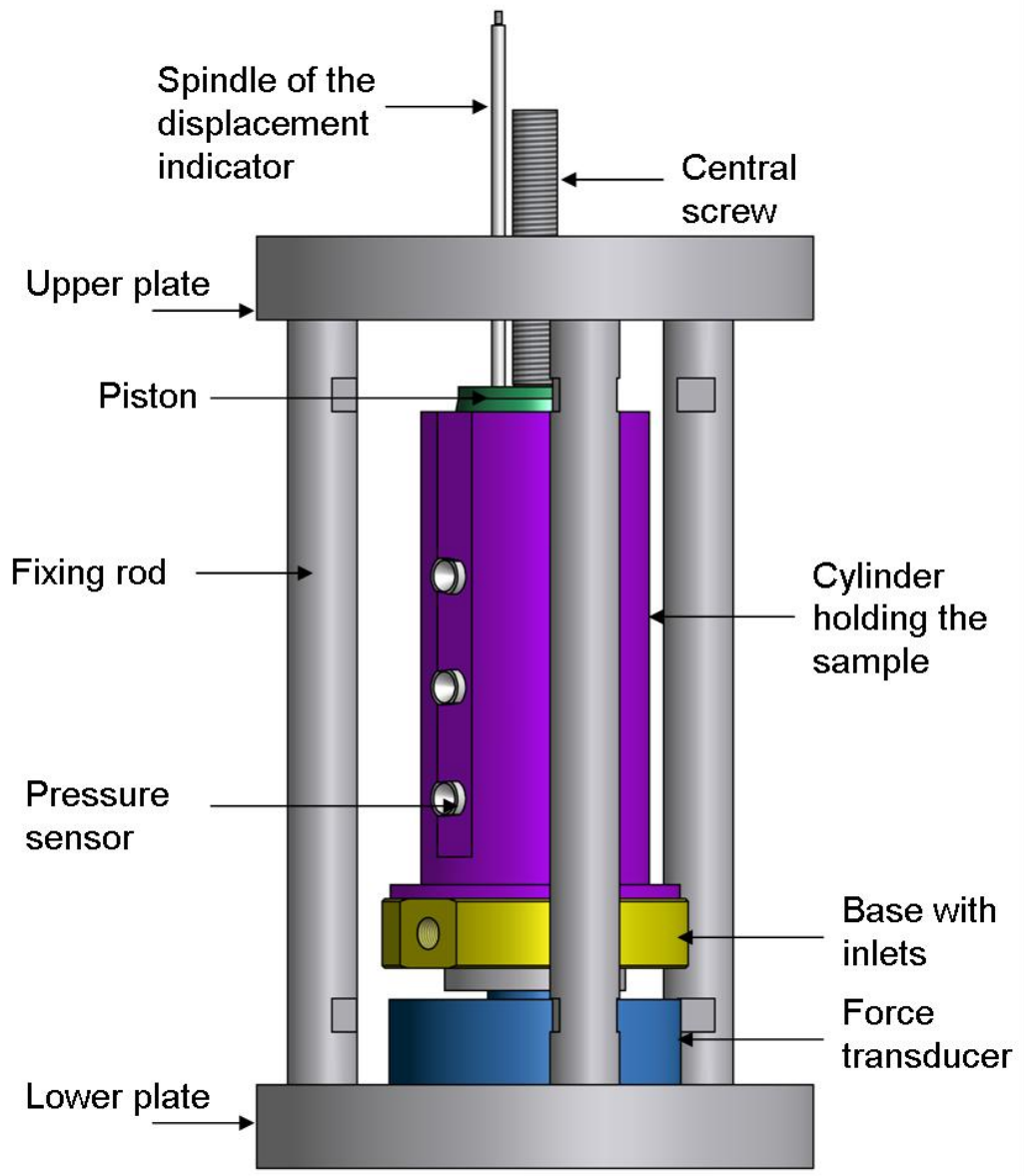

Figure 3. 3D view of the column. 


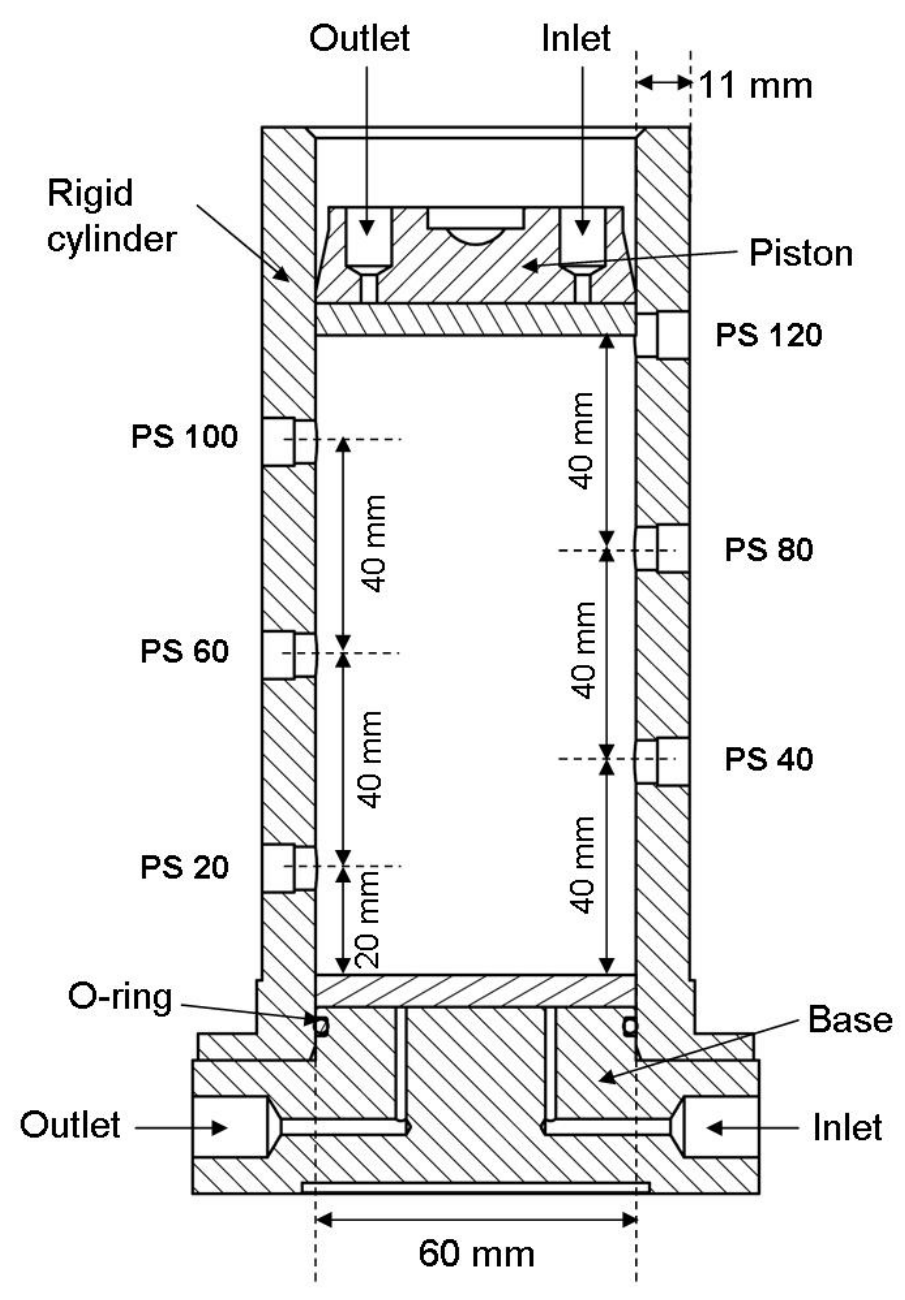

Figure 4. Cross section of the column with the positions of the pressure sensors (PS). 


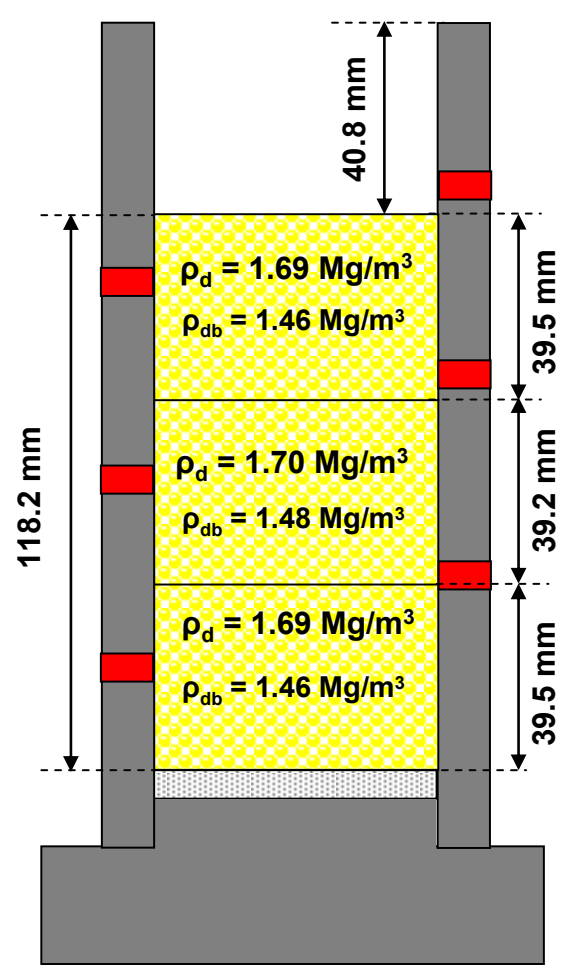

Figure 5. Dimensions and final dry densities of the layers of the compacted soil specimen

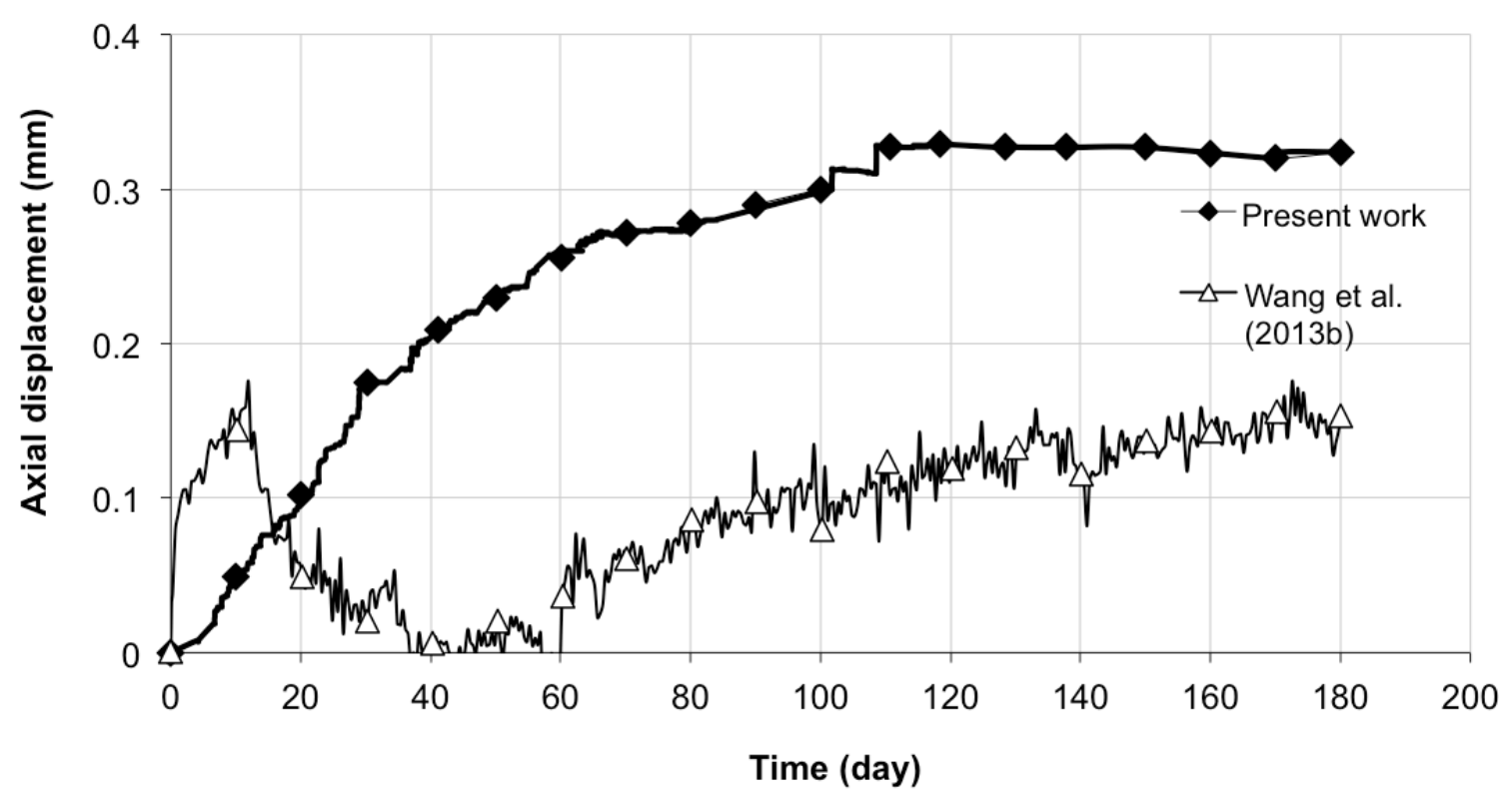

Figure 6. Piston's axial displacement versus time. 


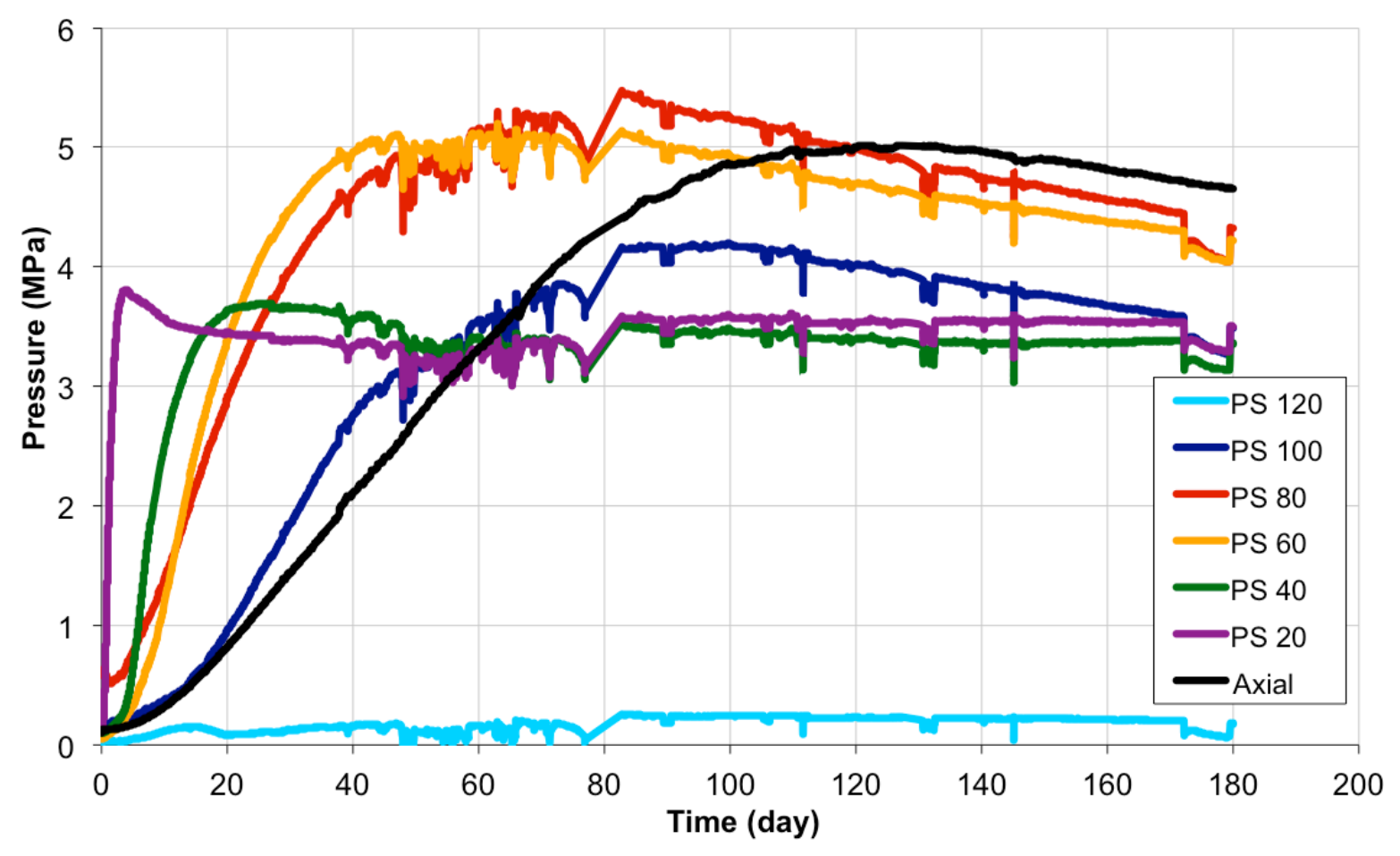

Figure 7. Swelling pressure versus time.

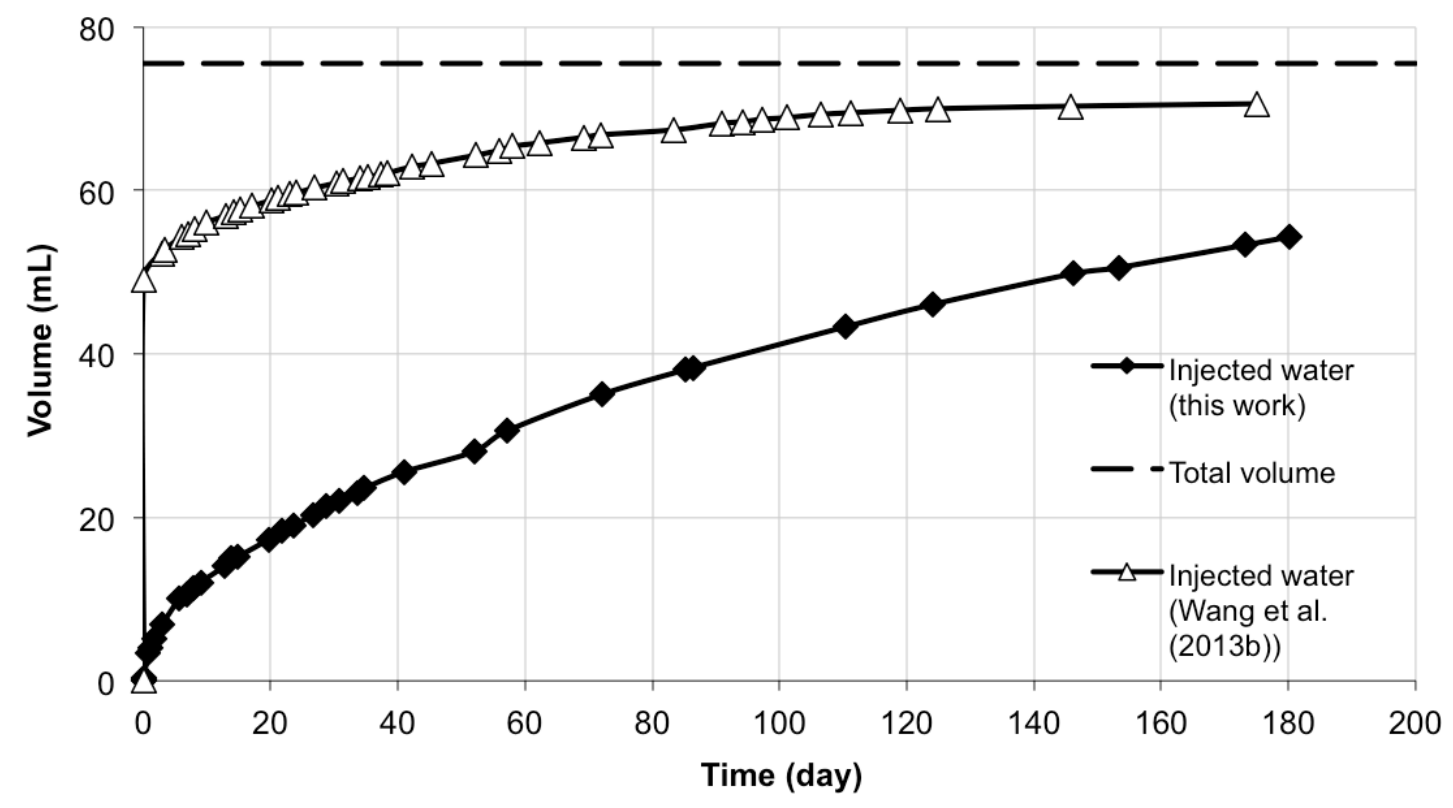

Figure 8. Volume of injected water versus time. 